\title{
Changes in Landholding Pattern in The Eastern Himalayan State of Assam Since Independence
}

\author{
Suparna Roy ${ }^{1}$ Niranjan $\operatorname{Roy}^{2 *}$ \\ ${ }^{1}$ Department of History, Assam University, Silchar-788011, Assam, India \\ ${ }^{2}$ Department of Economics, Assam University, Silchar-788011, Assam, India \\ *Corresponding Author Email: royniranjan3@gmail.com
}

Received: 02.04.2021; Revised: 24.05.2021; Accepted: 30.05.2021

CSociety for Himalayan Action Research and Development

\begin{abstract}
After the annexation of Assam in 1826, the British recognised certain estates created during Ahom rule but felt alterations in land use policy and enacted Regulations accordingly. The Land and Revenue Regulation 1886 governed the land relations during the colonial period and continued after independence in Assam. The land reforms were initiated in the state and the country as a whole in the post-independence period. The study observed that significant inequalities prevail even after 70 years of adoption of land reforms measures regarding operational holdings among different size classes. The research suggests a holistic approach in land reforms implementation considering the agriculture sector's dependency on economic development in the state.
\end{abstract}

Keywords: Land Reforms • Operational Holdings • Inequalities • Land Distribution • Size of Holdings

\section{Introduction}

Land reform has been considered a robust institutional framework for egalitarian justice regarding the redistribution of land to the tillers. New land rules acknowledge that past growth has eroded rural welfare, while reformers hold the same twin hopes for macroeconomic growth with farm stability. Yet with that growth, the state must reregulate farmland, risking the legitimacy and political stability garnered from the prior settlement (McDonald 1997). The state of Assam was one of the forerunners in the country in respect of the implementation of agrarian reforms. In fact, before India's independence, the latest Annual Report of the Department of Agriculture, Assam was prepared for 1945-46 under the supervision of R.C. Woodford, who had been the Director of Agriculture, Assam. Since 1941-42 the department worked on the Improved Seed Paddy Multiplication Scheme. Primarily improved seeds produced on Government farms were issued to a set of selected registered farmers who multiply these in their holdings under the department's supervision. In addition to the seeds and manures published under Grow More Food Seeds, and Manure Distribution scheme, considerable quantities of vegetable seeds and large numbers of vegetable seedlings were issued to the public through the departmental seed depots. It was a matter of great satisfaction that Assam stood up very well to the highly increased demand for fresh vegetables from the civil population and the army. The Government of Assam, since independence, had taken the initiative for enacting laws for agrarian reforms with the principles of social and spatial settlements. The object of land reform laws to Assam was to provide security of tenure to the cultivator, protect him from the exploitation of big landowners and tenure holders, and establish a direct relationship with the government and fix the ceiling on land holdings. With this end in view, a series of legislative measures have been taken since attaining independence.

The present study attempted to examine the land laws enacted immediately after the independence and subsequent revisions allowing ownership and changing scenario of land holding pattern during 
the last seventy years. A map of the state of Assam is shown in map-01.

\section{Map-01 State of Assam}

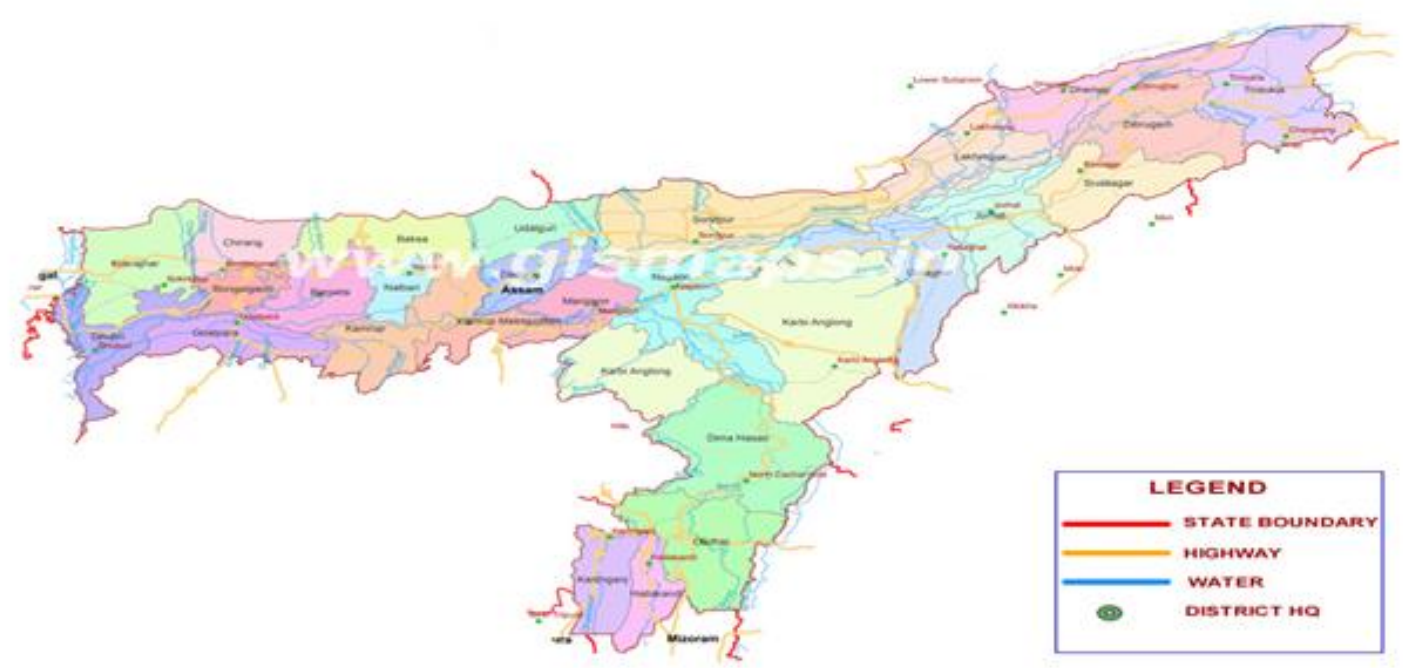

\section{Data and Methods}

The present study is based on both primary and secondary materials. The primary materials were collected from the Assam State Archives, Guwahati, and secondary materials from different Agricultural Census by the Ministry of Agriculture, Government of India. Combinations of various statistical and graphical techniques have been used for the present study. The Growth rate is calculated using two time periods from the base year 1970-71 and current year 2015-16 based on data from Agricultural Census by using the formula:

Current year - Base Year
Growth Rate------------------------- x 100
Base year

The Gini coefficient is calculated using the formula:

Gini coefficient formula

$\frac{1}{10000}\left[\sum \mathbf{X}_{\mathrm{i}} \mathbf{Y}_{\mathrm{i}+1}-\sum \mathrm{Y}_{\mathrm{i}} \mathbf{X}_{\mathrm{i}+1}\right]$
The value of Gini coefficient ranges from o (perfect equality) to 1 (perfect inequality)

\section{The State of Assam:}

Assam's state comprises three physical divisions, namely, the Brahmaputra Valley, the Barak Valley and the Hill range. The Brahmaputra Valley, which forms the northern part, is the most significant, comprising 71.7 per cent of the state's total geographical area. On the other hand, the Barak Valley region, which forms the southern part, is comparatively smaller. The two Valleys derived their names from the respective main rivers, the Brahmaputra and the Barak flowing through East to West in the Valleys. The hill regions formed by the Karbi-Anglong and the North-Cachar hills stands separated the two valleys from the middle. The Barak Valley region covers an area of $6922 \mathrm{sq}$. $\mathrm{km}$. The valley constitutes 8.9 per cent of the state's geographical location, but it contains 11.22 per cent of the population as per the 2001 census. The region shares a border with the North-Cachar hills district and the state of Meghalaya in the North; the state of Manipur in the East; the state of Mizoram in the South and the state of Tripura and the Sylhet district of Bangladesh in the west (refer map-01). 
During the British period, Assam was created as a separate province in 1874 with the present hill and plains districts and the districts of Sylhet (now part of Bangladesh). But for the few years after the first partition of Bengal in 1905, the provinces of East Bengal and Assam were created. The area maintained this composition until India's section in 1947, when the bulk of the Sylhet district, except for portions of Karimganj sub-division (now part of Karimganj district), went to Pakistan after a referendum. Assam consisted of five autonomous hills districts (Garo hills, United Khasi and Jaintia hills, Mikir hills, Mizo district and North Cachar hills) and plains areas. These hills districts are not a continuous landmass. The Mizo district was utterly cut off from the rest of the continent by the present district of Cachar. The other four districts were not accessible to each other over the hills. These were approachable only by roads passing through the plains districts of Assam, as there were no lateral communications between one hill district and another. The communication network has developed following the natural features of the valleys of the Brahmaputra and the Barak ${ }^{1}$ except North Cachar hills district all other autonomous districts became part of the states of Meghalaya and Mizoram.

\section{Land management during British period}

When the British extended their rule to Assam in 1826, they recognised certain estates created during Ahom rule. But for the convenience of land revenue administration, the existing system had to be reviewed and alterations made when necessary (Goswami 1969). In Assam, ' Land and Revenue Regulation 1886' governed the land relations during the colonial period and continued after independence. The 1886 Regulation provided for state ownership of lands. The Ahom King in Assam claimed to be the owner of all lands within his territory and made extensive grants to temples, priests and charitable institutions. These were revenue free and were known as Lakhiraj grants. But the bulk of the lands were allotted to paiks instead of services. According to a set pattern, a paik was an ordinary citizen who had to render assistance to the king or his officers or the temples. When the British annexed Assam, they welcomed the theory of state ownership of all land due to two reasons: (1) in England, the same theory prevailed since the Norman Conquest and (2) it opened the prospect of reaping a rich harvest of revenue (Das 1986). The British rulers recognised only the Debottor lands as Lakhiraj and assessed all other grants by Ahom rulers for half-revenue and known as Nisf-Khiraj.

The large scale depopulation on the eve of annexation enabled the British to restructure the landholding pattern for revenue maximisation. This was effected by two methods: by recognising the private ownership of land and secondly by encouraging immigration from outside. They found that only one-fifth of the total areas were under actual cultivation. They declared the existing individual occupants as the owner granted them pattah and declared them to be Mirasdars as they paid rent directly to the Government. The forests, mines, fisheries and ferries were made reserved. The rest of the tract was declared wasteland, and the Bengal Waste Land Rule was brought in to operation. The Government then began to settle newcomers in these wastelands (Roy 2007).

Excepting Goalpara district and Karimganj subdivision of Cachar district, the whole of the Assam plains, by and large, has the ryotwari system of land tenure. The tea grants given under the Waste Land Settlement Rules constitute another type of estates. The principal types of land tenure in Assam at the time of independence were: (1) permanently settled estates; (2) revenue-free estates; (3) wasteland settlement grants; and (4) temporarily settled estates. Under the temporarily settled estates, there are annual and periodically settled estates. Periodically settled estates are settled for 10 to 30 years. After the expiry of the period Government may alter the land revenue but cannot evict the landholder. Even before independence, attempts were made to regulate tenants' status and rights by the Goalpara Tenancy Act of 1929, Sylhet Tenancy Act of 1936 and Assam (Temporarily Settled District) Tenancy Act of 1935 (Goswami 1969). 
During the British period, the state was the ultimate owner of all lands and recognized three classes of persons who held lands under it, namely, proprietors, landholders and settlement holders. Six prominent Zamindar families of Goalpara and thousands of petty Zamindars of Sylhet (including Karimganj), the Lakhirajdars of temples and satras and the owners of fee-simple tea estates roughly comprised the class of proprietors. The periodic leaseholders, including Nisf Khirajdars and numerous revenue paying tea estates, were the landholders. Annual leaseholders were the settlement holders (Das 1996). The Department of Agriculture, Assam spent Rs.33,000 and Rs.84,700 in 1943-44 and 1944-45 respectively to distribute seed potatoes and pulse and vegetable seeds in these areas. The response from the cultivators was very satisfactory. The department conducted extensive propaganda among cultivators for increasing the production of food, stress being laid in particular on (1) doublecropping paddy (2) Use of improved seeds (3) Adoption of suitable cultural and manorial practices (4) Substitution of food for non-food crops and (5) Cultivation of all waste or fallow land as far as possible. During the year 1945-46 new grow more food scheme was launched such as (1) Horticultural Development scheme (2) Dairy Development Scheme (3) Poultry Development scheme (4) Improved Ahu paddy Seed Production Scheme (5) Cattle Rehabilitation scheme (6) Agricultural Training scheme and (7) Transport scheme ${ }^{2}$

\section{Agrarian reforms after independence:}

\section{Contours of reforms}

The principal types of land tenure in Assam at the time of independence were: (1) permanently settled estates; (2) revenue-free estates; (3) wasteland settlement grants; and (4) temporarily settled (Goswami, 1969). Assam was one of the country's top states regarding the promulgation of land reforms even before independence. The Goalpara Tenancy Act of 1929, Sylhet Tenancy Act of 1936 and Assam (Temporarily Settled District) Tenancy Act of 1935 were enacted to safeguard the tenants' interest. Under Chapter 10 of the Assam Land and Revenue Regulation Law, 1886 of the British Government, the Assam Government later implemented in 1947 to protect the aboriginal backward protected tribal population from immigrants. This was mainly applicable in regions where they were predominant at the time of creation (comprising $50 \%$ or more of the population) as they were primitive and largely backward. The Government of Assam passed legislation in 1947 in this respect. During the first decade after independence a large number of land reform legislation were enacted by the state government.

The object of land reform laws to Assam after independence was to provide security of tenure to the cultivator, protect him from the exploitation of big landowners and tenure holders, and establish a direct relationship with the government to fix a ceiling on land holdings. With this end in view, a series of legislative measures have been taken since attaining independence. The Land Reform Laws contain the following enactments: (1) The Assam Adhiar Protection and Regulation Act 1948 (2) The Assam State Acquisition of Zaminadaries Act, 1951 (3) The Assam Fixation of Ceiling on Land Holdings Act, 1956 (4) The Assam State Acquisition of Lands Belonging to Religious or Charitable Institutions of Public Nature Act 1959 (5) The Assam Consolidation of Holdings Act, 1960 (6) The Assam Gramdhan Act, 1961 (7) The Assam Bhudan Act, 1965 and (8) the Assam (Temporarily Settled Areas) Tenancy Act, 1971.

The Assam Adhiar Protection and Regulation Act 1948 intended to regulate crop sharing to safeguard the share croppers' interest. In 1951 the Assam State Acquisition of Zaminadaries Act was passed. It provides for the acquisition by the state in the permanently settled areas of the state. The Assam Fixation of Ceilings on Landholding Act, 1956 was enacted in 1957 to impose a limit on the amount of land that a person may hold. To provide for acquisition by the state of lands belonging to religious and charitable institutions, the Assam State Acquisition of Lands Belonging to Religious 
or Charitable Institutions of Public Nature Act 1959 was passed. Then the Assam Consolidation of Holdings Act, 1960, the Assam Gramdhan Act,1961 and the Assam Bhudan Act, 1965 was enacted. The most important legislative measure taken to regulate the relationship of landlord and tenant and enable the cultivating tenant to become the owner of the land is the enactment of the Assam (Temporarily Settled Areas) Tenancy Act, 1971. The Adhiar Protection Act was repealed as the crop shares were given the status of tenants. This Act has been extended throughout the plain districts of Assam, including the erstwhile permanently settled areas of the state ${ }^{3}$.

Table 1: Estimated number of operational holdings in Assam as in 1960-61 and 1970-71

\begin{tabular}{|c|c|c|c|c|}
\hline \multirow{2}{*}{$\begin{array}{l}\text { Size classes } \\
\text { of }\end{array}$} & \multicolumn{2}{|c|}{$\begin{array}{l}\text { Operational } \\
\text { holdings }\end{array}$} & \multicolumn{2}{c|}{$\begin{array}{l}\text { Percentage of } \\
\text { area operated }\end{array}$} \\
\cline { 2 - 5 } $\begin{array}{l}\text { holdings } \\
\text { (hectares) }\end{array}$ & $\begin{array}{l}1960- \\
61\end{array}$ & $\begin{array}{l}1971- \\
72\end{array}$ & $\begin{array}{l}1960- \\
61\end{array}$ & $\begin{array}{l}1971- \\
72\end{array}$ \\
\hline Up to 0.02 & 5.35 & 7.73 & 0.24 & 0.86 \\
\hline $0.21-0.40$ & 8.95 & 12.01 & 1.66 & 2.79 \\
\hline $0.41-1.00$ & 25.99 & 32.66 & 11.49 & 17.99 \\
\hline $1.01-2.02$ & 74.01 & 82.63 & 30.28 & 34.90 \\
\hline $2.03-3.03$ & 12.91 & 10.01 & 20.68 & 18.59 \\
\hline $3.04-4.04$ & 5.51 & 4.29 & 11.65 & 11.95 \\
\hline $4.05-5.05$ & 2.91 & 1.70 & 7.77 & 5.59 \\
\hline $5.06-6.07$ & 1.22 & 0.59 & 3.94 & 2.52 \\
\hline $6.08-8.09$ & 1.76 & 0.48 & 5.35 & 2.59 \\
\hline $8.10-10.12$ & 0.38 & 0.22 & 1.89 & 1.50 \\
\hline $10.13-12.14$ & 0.15 & 0.05 & 1.00 & 0.42 \\
\hline $12.15-20.24$ & 0.15 & 0.03 & 1.61 & 0.30 \\
\hline $20.25-$ & - & - & 0.44 & - \\
\hline above & & & & \\
\hline
\end{tabular}

Source: NSS Reports on Landholdings (as reported in Phukan (1990) ${ }^{4}$

\section{Operational Holdings up to 1970-71}

The marginal and small farms dominate the agricultural scene in Assam. It is observed that the proportion of small and marginal farms has increased in the state. There is also a large area still under annual lease, namely about $20 \%$ of the total settled area. While the security of tenure has been assured to private tenants bypassing the new Tenancy Act, 1971, the same protection has been denied by the government to its direct settlementholders (Das 1996).

The Assam Fixation of Ceiling on Land Holdings Act, 1956 came into force on 15th February 1958. The surplus land available for acquisition on that basis was estimated to be 4 lakh bighas. However, the purchase progress was not very speedy, primarily because of the different tiers of appeals as prescribed in the Act and Rules. The total area of land acquired under the Act of 1956 comes to 2,70,136 bighas. The ceiling Act was amended in 1970, and the limit of lands retainable by a person was reduced from 150 to 75 bighas. This was further amended on 17th September 1975, bringing down the ceiling from 75 to 50 bighas for individual holdings. By 30th June 1976, a total area of 1532,654 bighas of ceiling surplus lands was acquired as against the preliminary estimated size of 12 lakhs bighas. The obtained site's progressive total as of 30th November 1976 was 17, 21,747 bighas (Das 1986).

Despite several land reform measures undertaken by the Government of Assam since independence in 1970-71, both small and marginal farmers predominate the state's land distribution pattern is 80.79 per cent taken together. The NSS data for 1960-61 and 1970-71 indicated that the proportion of holdings within 2.02 hectares in 1960-61 was 74.01 per cent and increased to 82.63 per cent in 1971-72. This is indicative of the fact that numbers of small and marginal farmers (up to 2.02 hectares) have increased over the period considerably (Table 1).

\section{Operational Holdings during 1970-71 to 2015-} 16

The period from 1970-71 is very significant in the context of agricultural development in Assam as modern technology started to be promoted by that period. In the meantime, agriculture in the state was plagued by small and fragmented landholdings. The structure of operational holdings affects the farm's economic efficiency 
and determines agricultural development pattern in a country.

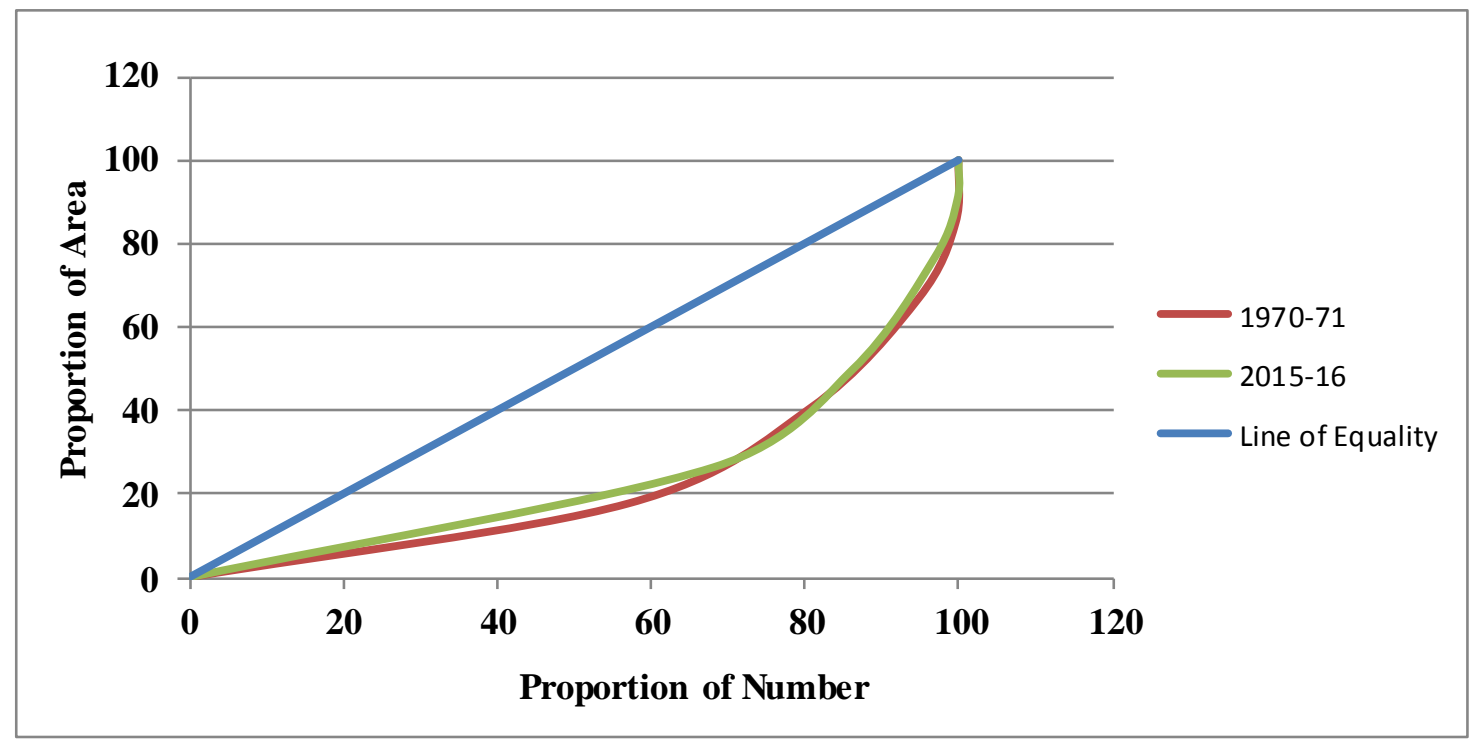

Fig 1: Lorenz Curve of Operational Land Holding, Assam (1970-71 and 2015-16)

The pattern of changes in the operational holdings during the period $1970-71$ to $2015-16$ in the state of Assam has been analysed, estimating the Growth rate and Gini coefficient. The Lorenz curve (Fig 1) shows inequalities of two time periods, 1970-71 and 2015-16. The time gap of 45 years is sufficient enough for inequality to decline. Japan's land reform of the late 1940s established farming households as the only legal owners of farmland and reinforced the smallholding pattern with strict laws against alienation and farmland accumulation. This was a politically inspired policy, and its influence endured in characteristic features of postwar Japanese society (McDonald 1997). Such a targeted approach in respect of land reforms has been missing in India. The overlapping curves of the two time periods clearly indicate that no improvement took place in this period in the state of Assam. The Gini coefficient value was 0.529 in $1970-71$, and it decreased to 0.495 in $2015-16$. The curve indicates that about $57 \%$ of operational holdings cover an area of $17 \%$ belonging to below 1.00-hectare category of farmers, $80 \%$ of holdings covers around $40 \%$ of the size, and 5\% of medium and large holdings possess $33 \%$ of the area in 1970-71. As per the Gini coefficient values, the situation has not improved and continues to be unequal in 2015-16. This situation has raised serious doubt about the efficacy and implementation of land reforms measures in the state of Assam. The findings of inequality in terms of Gini coefficient values have been substantiated by growth analysis in area and operational holdings across different size classes during 1970-71 and 2015-16 as depicted in (Fig 2) 


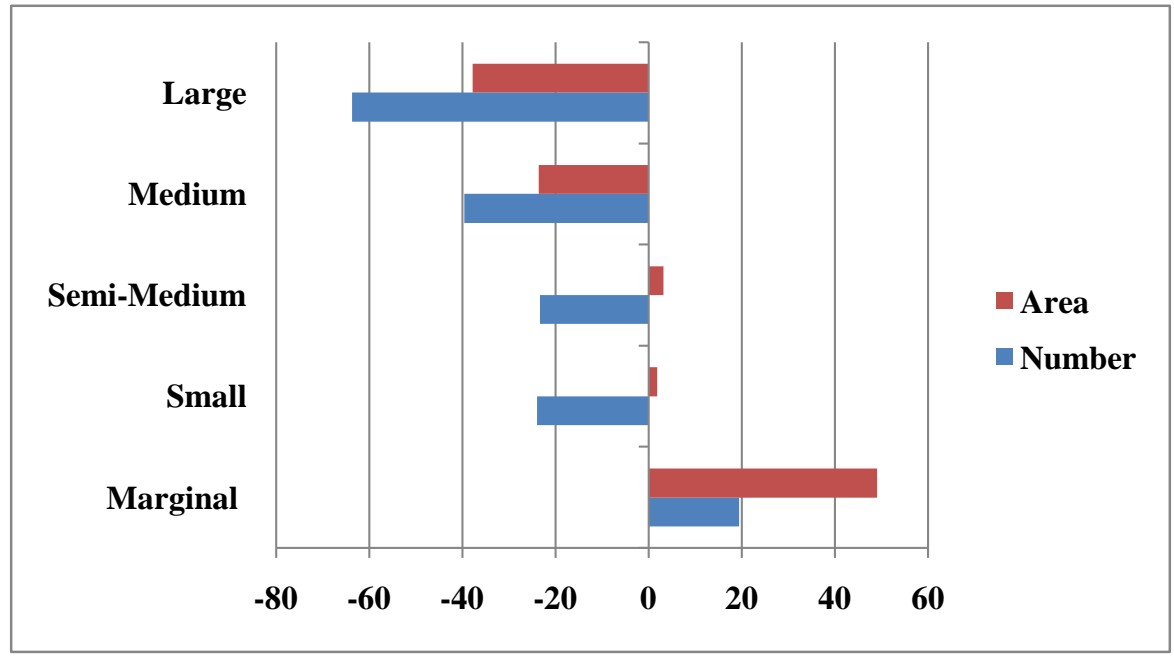

Fig 2: Growth in Area and Operational Land Holdings, Assam (1970-71 and 2015-16

The bar shows positive growth in area and number of operational holdings of marginal farmers (below 1.0 hectare) and size to a bit of extent in case of small and semi-medium category of landholdings. The number of operational holdings in small and semi-medium cases, both area and number in cases of medium and large classes of holdings, registered negative growth during the period under study. A detailed account of the distribution of location and number of operational holdings among different size classes is depicted in Table-2.

Table-2 Area and number of operational holdings in Assam during 1970-71 to 2015-16

\begin{tabular}{|c|c|c|c|c|c|c|c|c|c|c|}
\hline \multirow{2}{*}{$\begin{array}{l}\text { Size class } \\
\quad \text { (in } \\
\text { hectares) }\end{array}$} & \multicolumn{2}{|c|}{ 1970-71 } & \multicolumn{2}{|c|}{ 1990-91 } & \multicolumn{2}{|c|}{ 2000-01 } & \multicolumn{2}{|c|}{ 2010-11 } & \multicolumn{2}{|c|}{ 2015-16 } \\
\hline & Number & Area & Number & Area & Number & Area & Number & Area & Number & Area \\
\hline $\begin{array}{c}\text { Marginal } \\
\text { (Below } \\
\text { 1.0) }\end{array}$ & 57.0 & 17.7 & 60.3 & 18.9 & 62.6 & 21.3 & 67.3 & 25.8 & 68.1 & 26.4 \\
\hline $\begin{array}{c}\text { Small } \\
(\mathbf{1 . 0}-2.0)\end{array}$ & 23.8 & 23.0 & 22.2 & 24.5 & 20.7 & 23.5 & 18.3 & 22.9 & 18.1 & 23.4 \\
\hline $\begin{array}{c}\text { Semi- } \\
\text { Medium } \\
(\mathbf{2 . 0 - 4 . 0 )}\end{array}$ & 14.0 & 26.3 & 13.6 & 28.6 & 13.0 & 30.8 & 11.2 & 27.3 & 10.8 & 27.1 \\
\hline $\begin{array}{c}\text { Medium } \\
(4.0-10.0)\end{array}$ & 4.8 & 18.0 & 3.8 & 15.3 & 3.5 & 16.0 & 3.1 & 14.6 & 2.9 & 13.8 \\
\hline $\begin{array}{c}\text { Large } \\
(10.0 \& \& \\
\text { above })\end{array}$ & 0.4 & 15.1 & 0.2 & 12.6 & 0.2 & 8.5 & 0.2 & 9.4 & 0.1 & 9.4 \\
\hline $\begin{array}{c}\text { All } \\
\text { Classes }\end{array}$ & 100.0 & 100.0 & 100.0 & 100.0 & 100.0 & 100.0 & 100.0 & 100.0 & 100.0 & 100.0 \\
\hline
\end{tabular}

Source: 1) Government of Assam, Report on Agricultural Census,1970-71, 1990-91, 2000-01, 2010-11 .

2) Agriculture Census, 2015-16, Agriculture Census Division, Department of Agriculture, CoOperation \& Farmers Welfare, Ministry Of
Agriculture \& Farmers Welfare Government of India. 


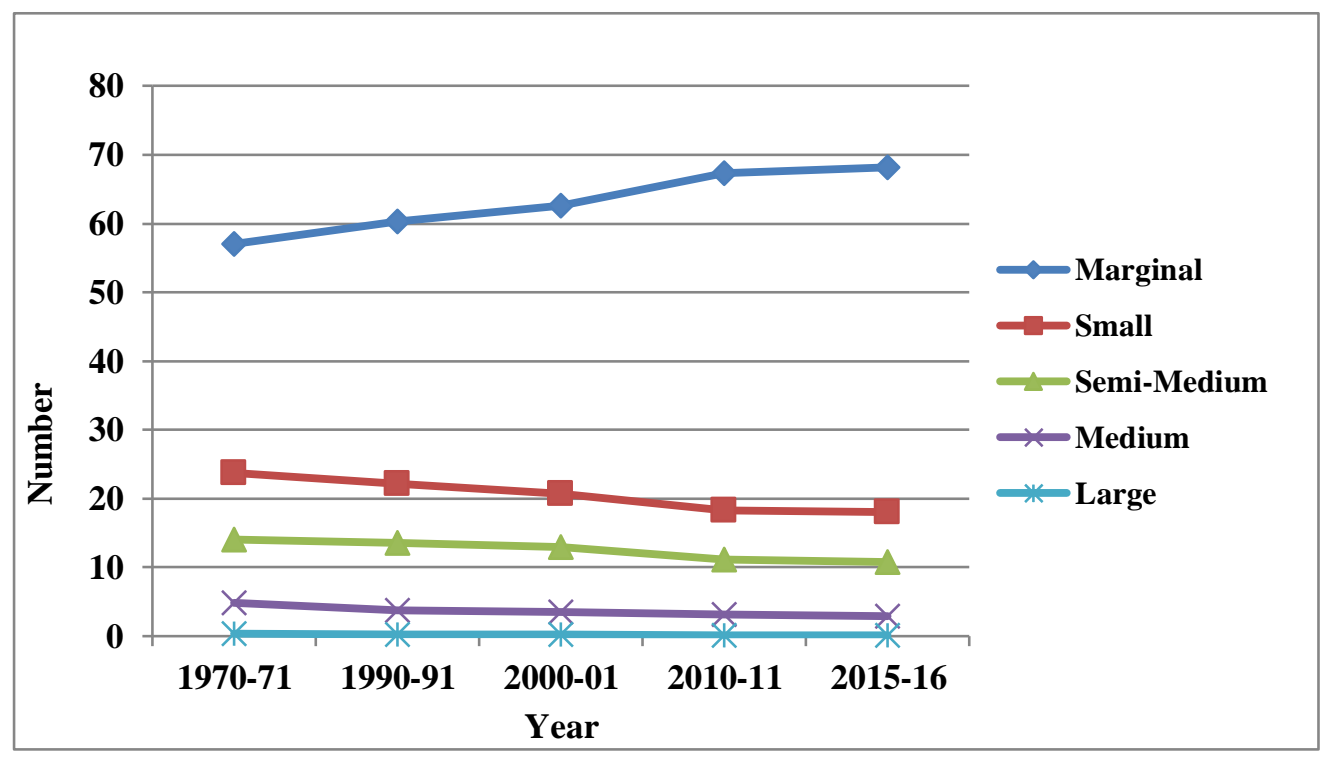

Fig 3: Number of operational holdings in Assam as per different Agriculture Censuses

Though there is a lengthy debate on the efficiency of smallholdings with respect adoption of modern agricultural technology, concerns also raised that an increase in small and marginal size farms led to lower growth of agricultural productivity in India. In all the five agricultural censuses during 197071 to $2015-16$, the number of operational holdings belonging to marginal size class has been steadily increasing in Assam. While there is a decline in small and semi-medium, several medium and large size holdings remains stable over the years. In respect of area operated, there is an increase in the marginal size class category (Figs 3 and 4).

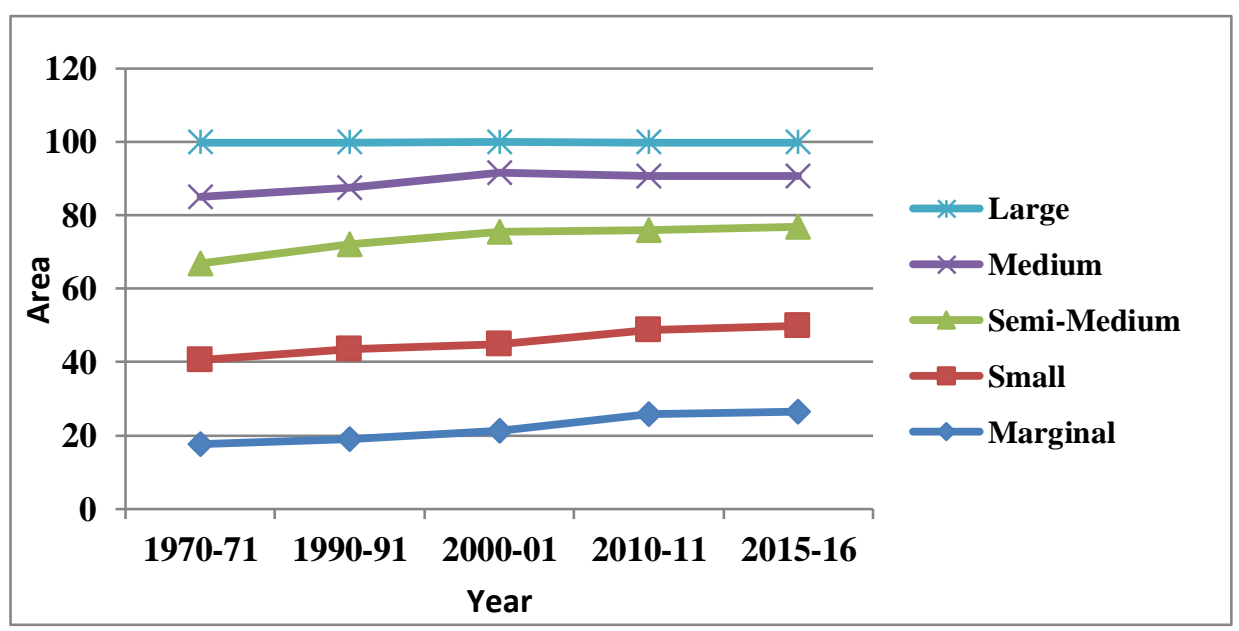

Fig 4: Area operated by operational holdings as per different Agriculture Censuses

Similarly the average size of holding during the period $1970-71$ to $2015-16$ has declined steadily from 1.47 to 1.09 hectare for the state of Assam and from 2.28 to 1.08 hectares for the country as a whole (Fig 5). 


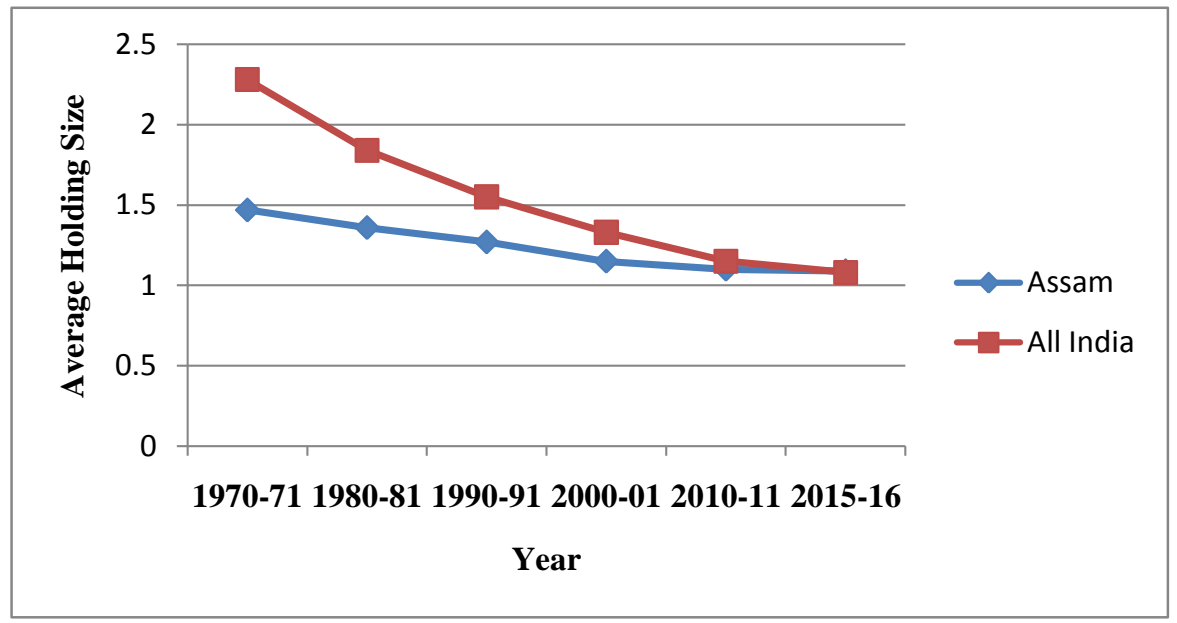

Fig 5: Average Size of Holding in Assam and All India, 1970-71 to 2015-16

Thus, in the two phases, viz, phase-I beginning independence up to $1970-71$ and phase-II beginning 1970-71 to date, the area under operational landholdings has decreased, and their number increased in the state. The increase in marginal and small-sized farms led to the disadvantageous situation so far as the extensive use of modern technology in the state is concerned. This is evident from the low productivity and lack of diversification of the agricultural sector in Assam. The existing land tenure system results from the past, where expanding population pressure on limited arable land results in excessive fragmentation of landholding. These small landholdings are highly uneconomic and stand as a barrier for the implementation of modem and advanced technology in the field of agriculture (Das 2000).

\section{Conclusion}

The state of Assam is an agriculture dominated economy. The enactment of land reforms measures brought a ray of hope in transforming the rural agricultural sector. Unfortunately, there are significant inequalities that prevail even after 70 years of adoption of land reforms measures. Some states in the country like West Bengal adopted the 'operation Borga' scheme in the mid1970 s for registering tenants for effective implementation of the Tenancy Act. Small and marginal farmers dominate the agriculture sector in the state. Despite legal provisions, no measures have been adopted for the consolidation of holdings. The increase in the small size of holdings over the years led agriculture to an uneconomic venture. Considering the dependency on agriculture by the large masses, the institutional framework needs to be very effective for agricultural transformation. A holistic plan of action in this regard is called for sustainable agricultural development in the state.

\section{Acknowledgement}

The authors duly acknowledged the funding of ICSSR, New Delhi for IMPRESS Research Project on "Agricultural Transformation in Northeast India since Independence" (2019-21).

\section{Notes:}

1.The Advisory Council of the Autonomous District Council etc., Assam, 1961- Secretariat Administration (Records and Library) Deptt., Assam Secretariat (C) Dispur, Guwahati-6, Tribal Areas and Welfare of Backward classes Department, July, 1961, Govt. of Assam.

2. Annual Report of the Department of Agriculture, Assam for the year ending March 1946, R.C. Woodford, Director of Agriculture, Assam, Shillong, printed at the Assam Government Press, 1948

3. Hand Book of Land Reforms, Assam modified up to $31-12-75$ by Govt. Publication: Gauhati 
Directorate of PTG., STY. Govt. of Assam, Assam State Archive Library, lib/R114/S4/39.

4. Study on the Investment and Return of the Agricultural Farming Corporation: Panbari, Dec1975, Secretariat Administration (Record and Library) Deptt,. Assam Secretariat, Dispur, Guwahati, Assam.

\section{Acknowledgement}

The authors duly acknowledged the funding of ICSSR, New Delhi for IMPRESS Research Project on "Agricultural transformation in Northeast India since Independence" for the period 2019-21.

\section{References}

Das, Dipak Chandra (2000) Agricultural Land Use and Productivity Pattern of Lower Brahmaputra Valley (1970-71 and 1994-95), Ph.D Thesis, North Eastern Hill University, Shillong (unpublished).

Goswami, PC (1969) Land Reform in Assam,

Reviewed Work(s): Land Problems and Land Reforms in Assam by Narendra Chandra, Economic and Political Weekly, Vol. 4, No. 42 (October 18, 1969), pp. 1662-1664

Das, JN (1986) "Land, Land-Relations and Land Reforms in the Plains and Valleys of Northeast India" in Atul Goswami (eds) Land Reforms and Peasant Movement: A Study of North- east India, Omsons Publications, Guwahati.

McDonald, Marry G (1997) Agricultural Landholding in Japan: Fifty Years After Land Reform, Geoforum, Vol. 28, No. 1, pp. 55-78, Elsevier Science Ltd, Great Britain.

Roy, Suparna (2007) Land System and Management in the Colonial Period (A Study of Barak Valley), Mittal Publications, New Delhi, 2007, pp.4

$$
* * * * * * *
$$

